\title{
Transscleral diode laser retinopexy in retinal reattachment surgery
}

\author{
Retinopexia com laser de diodo transescleral na cirurgia dedescolamento de retina
}

\author{
João Carlos de Miranda Gonçalves ${ }^{1}$ \\ Michel Eid Farah²
}

Study carried out at the Retina and Vitreous Unit, Ophthalmology Department, São Paulo Federal University - UNIFESP

${ }^{1}$ Mestre e Doutor em Oftalmologia pela Universidade Federal de São Paulo

${ }^{2}$ Professor Adjunto Livre-docente do Departamento de Oftalmologia da Universidade Federal de São Paulo Supported by CNPq (Conselho Nacional de Desenvolvimento Científico e Tecnológico).

Address for correspondence: Gonçalves, JCM, Rua Paulo Bregaro, 260 - São Paulo (SP) - CEP 04261-000 E-mail: joaocg@uol.com.br

Recebido para publicação em 06.12.2002

Versão revisada em 08.03.2003

Aprovação em 09.05.2003

\begin{tabular}{|l|}
\hline ABSTRACT \\
\hline Purpose: Transscleral diode retinal photocoagulation (diopexy) is beco- \\
ming an accepted technique in the treatment of selected retinal diseases. \\
The objective of this study is to evaluate diopexy technique in the pro- \\
duction of adhesive chorioretinal lesions during the surgical treatment of \\
the rhegmatogenous retinal detachment. Methods: 25 patients with rhe- \\
gmatogenous retinal detachment were enrolled in a prospective clinical- \\
surgical study to evaluate the technique of transscleral diode laser pho- \\
tocoagulation to obtain adhesive chorioretinal lesions during retinal \\
reattachment surgery. The surgery consisted of the placement of an \\
exoplant silicon to produce a buckle effect combined with a drainage of \\
subretinal fluid in most cases. Results: By a mean follow-up of 10 months, \\
21 of 25 eyes had theirretinas reattached afteronly one surgery with diopexy \\
used in all cases. Conclusion: Transscleral diode laser photocoagulation \\
was a technically easy, controlled, effective, reproducible and safe means \\
of obtaining chorioretinal adhesion in retinal reattachment surgery. \\
\hline
\end{tabular}

Keywords: Sclera; Retina/physiopathology; Choroid/physiopathology; Laser coagulation; Retinal detachment/surgery; Drainage

\section{INTRODUCTION}

Retinal reattachment surgery for rhegmatogenous retinal detachment combines the closure of a retinal break with methods that increase retinal adhesion such as cryotherapy, diathermy and laser photocoagulation ${ }^{(1-2)}$.

Due to technical difficulties or complications related to the use of diathermy and cryotherapy ${ }^{(3)}$, other means of obtaining chorioretinal adhesion has been studied. Transscleral diode retinopexy (diopexy) is an alternative way of inducing such adhesion as shown by previous investigators $^{(4-5)}$. The objective of this study is to evaluate through a prospective clinical-surgical study, the technique of diopexy in the genesis of adhesive chorioretinal lesions by retinal reattachment surgery.

\section{PATIENTS AND METHODS}

After an approval from the Institutional Ethics in Research Committee, 25 consecutive eyes underwent retinal reattachment surgery. Inclusion criteria were presence of idiopathic rhegmatogenous retinal detachment, age 20 to 60 years, absence of proliferative vitreoretinopathy (PVR) grade B or $\mathrm{C}^{(6)}$, retinal breaks smaller than $30^{\circ}$, no previous ocular surgery, retinal detachments lasting fewer than 12 months and informed consent signed by the patient. Complete preoperative examinations were performed and 
patients were examined on day 1 , week 1 , week 4 and then monthly after the procedure.

After retinal break localization under indirect ophthalmoscopy and scleral suture placement, the transscleral diode laser probe (IRIS Medical Instruments Inc, Mountain View, California) was placed against the external surface of the sclera (Figures 1 and 2). The red aiming beam was observed with an indirect ophthalmocope. Laser energy was delivered by depressing a foot pedal. Settings were $500 \mathrm{mw}$ for power and 2 seconds for duration. The ophthalmoscopic endpoint was mild whitening in the sensory retina and retinal pigment epithelial cells. When the endpoint was reached, diopexy was interrupted by releasing the pressure on the footswitch.

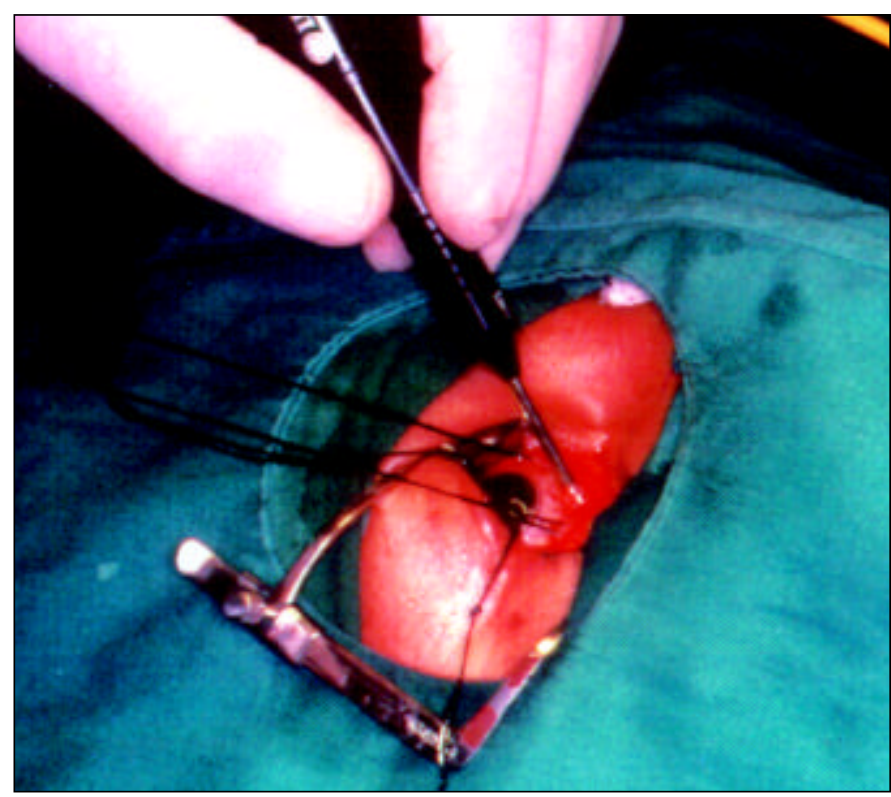

Figure 1 - Photography showing the application of transscleral laser during retinal reattachment surgery

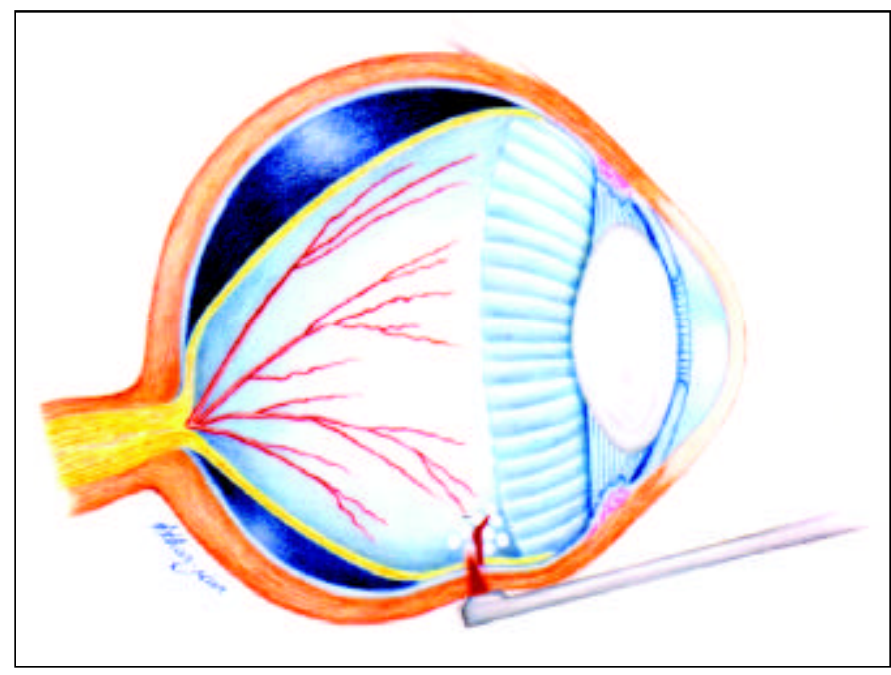

Figure 2 - Schematic drawing showing the moment of application of transscleral diode laser
Two rows of laser coagulations were placed around retinal breaks and areas of lattice degeneration. Subretinal fluid drainage was done in cases of excessive amount of fluid. If necessary, intravitreal injection of a balanced salt solution was used to fill the vitreous cavity. In such cases diopexy was performed after the drainage to allow retina uptake. A segmental circumferential silicone element and a 240-encircling band were placed in all cases.

\section{RESULTS}

Table 1 and graphs 1 and 2 show characteristics of the studied population regarding gender, age, race, affected eye, period of symptoms, presence of macular detachment, preoperative and postoperative visual acuity, cure and follow-up period.

The mean follow-up period was 10.5 months. All surgeries were done by the same investigator (JCMG). Twenty-one eyes had the retina $(84 \%)$ successfully reattached with a single surgery without the need of any additional photocoagulation, diathermy or cryotherapy. In one patient it did not reattach probably due to a non-identified break but this case was not submitted to another procedure. In the remaining three patients the retina redettached after a mean follow-up period of 3 months due to PVR formation and they had undergone vitrectomy.

In one case the occurrence of a nasal subretinal hemorrhage at the drainage site but without macular lesion was observed. The chorioretinal burn was similar to that observed in cases of argon laser photocoagulation or diathermy, with small white dots at the beginning and then, after 2 to 4 weeks, they became pigmented. In all cases the planned chorioretinal reaction was obtained with the chosen parameters. At the moment the chorioretinal burn was obtained the footswitch was put off and this way the exposure time was reduced.

Three patients presented Brüch's membrane rupture at the diopexy application, easily recognized by an audible "pop" and the presence of a hemorrhagic dot. In such cases the power settings were lowered and the treatment completed. These occurrences did not render any clinical major complication except in one patient who developed a mild intravitreal hemorrhage with spontaneous clearing after 5 weeks. No conjunctival or scleral damage were observed in these places where the laser was applied.

\section{DISCUSSION}

Three different thermal therapy modalities can be employed in order to create chorioretinal adhesion during retina reattachment surgery ${ }^{(7-8)}$. The main risks of diathermy are scleral shrinkage, tissue necrosis and chorioretinal hemorrhage ${ }^{(9)}$. Cryopexy has drawbacks as well as including development of postoperative cystoid macular edema, dispersion of retinal pigment epithelial cells and breakdown of the blood-retinal barrier, resulting in an increase in the potential for stimulation of PVR ${ }^{(3,10)}$. Transscleral laser photocoagulation with diode laser 


\begin{tabular}{|c|c|c|c|c|c|c|c|c|c|c|}
\hline $\begin{array}{l}\text { Patient } \\
\text { number }\end{array}$ & Gender & Age & Race & Eye & $\begin{array}{l}\text { Symptom } \\
\text { period }\end{array}$ & $\begin{array}{l}\text { Macula } \\
\text { status }\end{array}$ & $\begin{array}{c}\text { Preoperative } \\
\text { VA }\end{array}$ & $\begin{array}{c}\text { Postoperative } \\
\text { VA }\end{array}$ & Cure & $\begin{array}{l}\text { Follow up } \\
\text { period }\end{array}$ \\
\hline 1 & $\mathrm{~F}$ & 35 & $B$ & OS & $5 \mathrm{mo}$ & Detached & $1 / 200$ & $5 / 200$ & Yes & $7 \mathrm{mo}$ \\
\hline 2 & M & 59 & W & OD & $28 d$ & Attached & $20 / 30$ & $1 / 200$ & No & $8 \mathrm{mo}$ \\
\hline 3 & M & 56 & W & OS & $9 \mathrm{mo}$ & Detached & $\mathrm{HM}$ & $20 / 200$ & Yes & $8 \mathrm{mo}$ \\
\hline 4 & $\mathrm{~F}$ & 37 & W & os & $14 d$ & Detached & $1 / 200$ & $20 / 40$ & Yes & $8 \mathrm{mo}$ \\
\hline 5 & $\mathrm{~F}$ & 27 & B & OS & $3 \mathrm{mo}$ & Attached & $20 / 40$ & $20 / 80$ & Yes & $10 \mathrm{mo}$ \\
\hline 6 & M & 27 & W & OD & $4 \mathrm{mo}$ & Detached & $5 / 200$ & $1 / 200$ & Yes & $9 \mathrm{mo}$ \\
\hline 7 & M & 20 & W & OD & $2 \mathrm{mo}$ & Detached & $20 / 400$ & $1 / 200$ & No & $12 \mathrm{mo}$ \\
\hline 8 & $\mathrm{~F}$ & 27 & W & OS & $20 d$ & Detached & $1 / 200$ & $20 / 100$ & Yes & $12 \mathrm{mo}$ \\
\hline 9 & M & 60 & W & OD & $2 \mathrm{mo}$ & Detached & $20 / 400$ & $20 / 100$ & No & $8 \mathrm{mo}$ \\
\hline 10 & M & 46 & B & OS & $8 \mathrm{mo}$ & Detached & $20 / 200$ & $20 / 100$ & yes & $8 \mathrm{mo}$ \\
\hline 11 & $\mathrm{~F}$ & 42 & B & OS & $5 \mathrm{mo}$ & Detached & $1 / 200$ & $20 / 200$ & yes & $24 \mathrm{mo}$ \\
\hline 12 & $M$ & 35 & $B$ & os & $2 \mathrm{mo}$ & Detached & $20 / 200$ & $20 / 200$ & Yes & $8 \mathrm{mo}$ \\
\hline 13 & $\mathrm{~F}$ & 40 & AS & OS & $7 d$ & Attached & $20 / 30$ & $20 / 30$ & Yes & $8 \mathrm{mo}$ \\
\hline 14 & $M$ & 24 & W & os & $15 d$ & Detached & $20 / 400$ & $20 / 80$ & Yes & $12 \mathrm{mo}$ \\
\hline 15 & M & 30 & B & OD & $2 \mathrm{mo}$ & Detached & $1 / 200$ & $20 / 100$ & Yes & $16 \mathrm{mo}$ \\
\hline 16 & $\mathrm{~F}$ & 32 & W & OS & $1 \mathrm{mo}$ & Detached & $1 / 200$ & $20 / 100$ & Yes & $8 \mathrm{mo}$ \\
\hline 17 & M & 22 & B & os & $14 d$ & Detached & $1 / 200$ & $20 / 100$ & No & $11 \mathrm{mo}$ \\
\hline 18 & $\mathrm{~F}$ & 33 & $\mathrm{~B}$ & OD & $4 \mathrm{mo}$ & Detached & $20 / 400$ & $20 / 200$ & Yes & $8 \mathrm{mo}$ \\
\hline 19 & M & 25 & B & os & $8 \mathrm{mo}$ & Attached & $20 / 20$ & $20 / 40$ & Yes & $8 \mathrm{mo}$ \\
\hline 20 & M & 44 & W & os & $21 d$ & Detached & $\mathrm{HM}$ & $5 / 200$ & Yes & $9 \mathrm{mo}$ \\
\hline 21 & $\mathrm{~F}$ & 28 & W & OS & $7 d$ & Attached & $20 / 30$ & $20 / 25$ & Yes & $14 \mathrm{mo}$ \\
\hline 22 & $\mathrm{~F}$ & 37 & AS & OD & $6 \mathrm{mo}$ & Detached & $5 / 200$ & $20 / 400$ & Yes & $9 \mathrm{mo}$ \\
\hline 23 & M & 29 & W & OD & $3 \mathrm{mo}$ & Detached & $20 / 400$ & $20 / 200$ & Yes & $16 \mathrm{mo}$ \\
\hline 24 & M & 52 & W & os & $4 \mathrm{mo}$ & Detached & $20 / 200$ & $20 / 200$ & Yes & $10 \mathrm{mo}$ \\
\hline 25 & M & 55 & B & OD & $9 \mathrm{mo}$ & Detached & $5 / 200$ & $20 / 400$ & Yes & $12 \mathrm{mo}$ \\
\hline
\end{tabular}

(diopexy) is an alternative way to create such adhesion. Previous studies have shown that diode laser, emitting light in the near infrared range, has good scleral transmission and achieves uptake in the retinal pigment epithelium and choroid presenting theoretical and practical advantages ${ }^{(11)}$ Furthermore, diopexy can be accomplished through silicone scleral exoplants ${ }^{(12)}$.

The transscleral application of the diode laser was approved by the FDA in 1997 and can be used in the treatment of the retina in retinopathy of prematurity, tumors, retinal breaks, rhegmatogenous retinal detachment and glaucoma ${ }^{(4,11)}$.

Similar to cryotherapy, diopexy is applied with the aid of a probe that is useful to produce an indentation effect approaching the retinal pigment epithelial cells and the neurosensory retina (Figures 1 and 2). Only cases of retinal detachment with a moderate or large amount of subretinal fluid needed drainage before the diopexy. This could be observed in this study. The probe was easily removed from the contact with the sclera right after the treatment without adherence to the sclera or conjunctiva, often observed with some models of cryotherapy units. Unlike cryotherapy, once obtained the chorioretinal spot did not disappear avoiding repeated application at the same place. This could happen with cryotherapy, breaking the blood-retinal barrier, releasing RPE cells and would be related to the occurrence of PVR in some cases ${ }^{(13)}$.

In this study it was observed that in black patients the treat- ment duration was shorter than in white subjects and this was due to the amount of pigment present in the RPE. Sometimes different retina areas of the same patient can present different RPE pigmentation and this is not always easily noted. That should be taken into account by the surgeon during the diopexy in order to avoid excessive application that could cause complications such as Brüch's membrane break and hemorrhage.

Reattachment of the retina was obtained with a single procedure in $84 \%$ of the operated cases. A second procedure increased the reattachment rate to $95 \%$. These reattachment rates are similar to those obtained by other authors ${ }^{(4-5,14)}$ in recent studies with diopexy employing cryotherapy in a group of patients with rhegmatogenous retinal detachment.

Future studies employing diopexy can amplify its use. It could eventually be useful during pneumatic retinopexy and neovascular glaucoma as an alternative to cryotherapy.

The authors have no proprietary interest in the equipment used in this study.

\section{CONCLUSIONS}

Transscleral diode laser photocoagulation was a technically easy, controlled, effective, reproducible, and safe means of obtaining chorioretinal adhesion in retinal reattachment surgery. Very few operative complications were observed. 


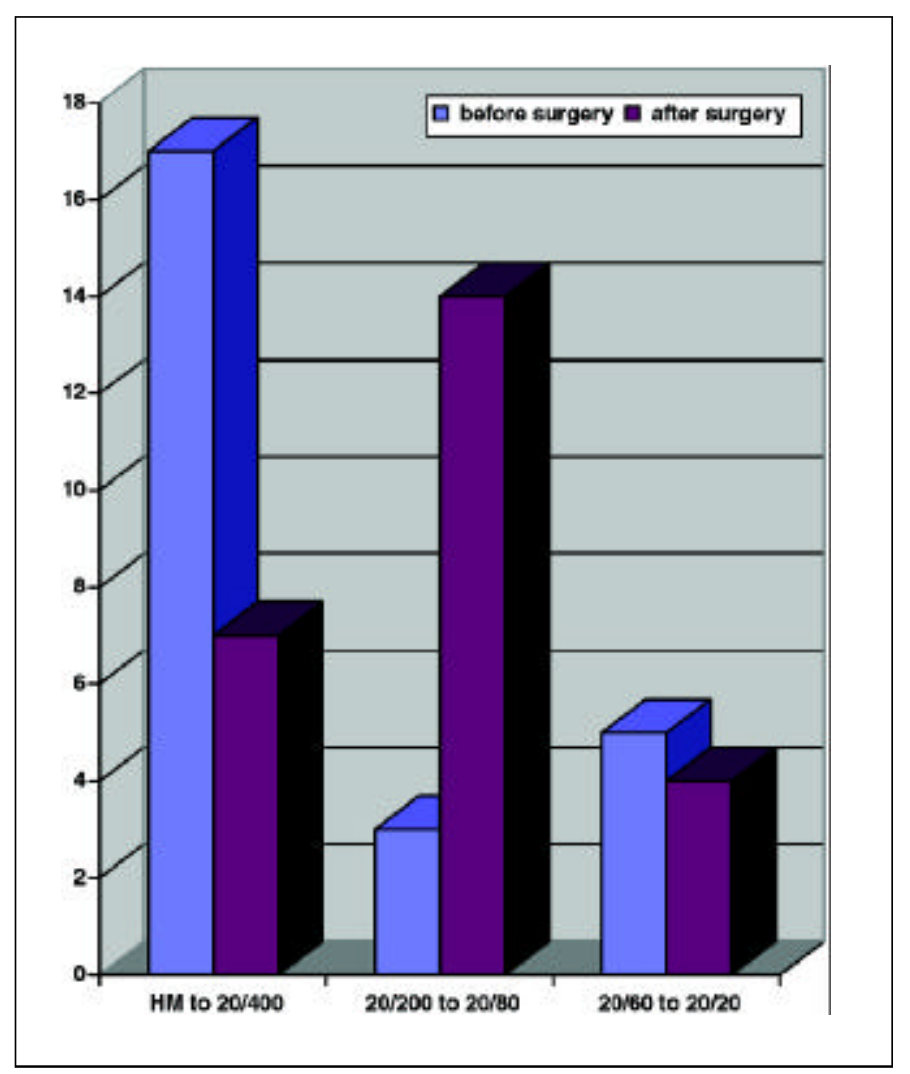

Graph 1 - Preoperative and postoperative visual acuities

\section{RESUMO}

Objetivo: Fotocoagulação transescleral com laser de diodo (diopexia) está se tornando técnica utilizada no tratamento de algumas doenças retinianas. O objetivo deste estudo é avaliar a técnica de diopexia na produção de lesões coriorretinianas aderentes durante o tratamento cirúrgico do descolamento de retina regmatogênico. Métodos: Vinte e cinco pacientes com descolamento de retina regmatogênico participaram deste estudo clínico-cirúrgico prospectivo para avaliar a técnica de fotocoagulação com laser de diodo transescleral para obter lesões coriorretinianas aderentes durante a cirurgia de descolamento de retina. A cirurgia consistiu de colocação de explante de silicone para produzir efeito de introflexão escleral combinado com drenagem do líquido subretiniano na maioria dos casos. Resultados: Após um período médio de seguimento de 10 meses, em 21 dos 25 olhos houve reaplicação da retina após um único procedimento cirúrgico com diopexia aplicada em todos os casos. Conclusão: Fotocoagulação com laser de diodo transescleral foi uma forma tecnicamente fácil, controlada, efetiva, reprodutível e segura na obtenção de adesão coriorretiniana na cirurgia de descolamento de retina.

Descritores: Esclera; Retina/fisiopatologia; Coróide/fisiopatologia; Coagulação por laser; Descolamento retiniano/cirurgia; Drenagem

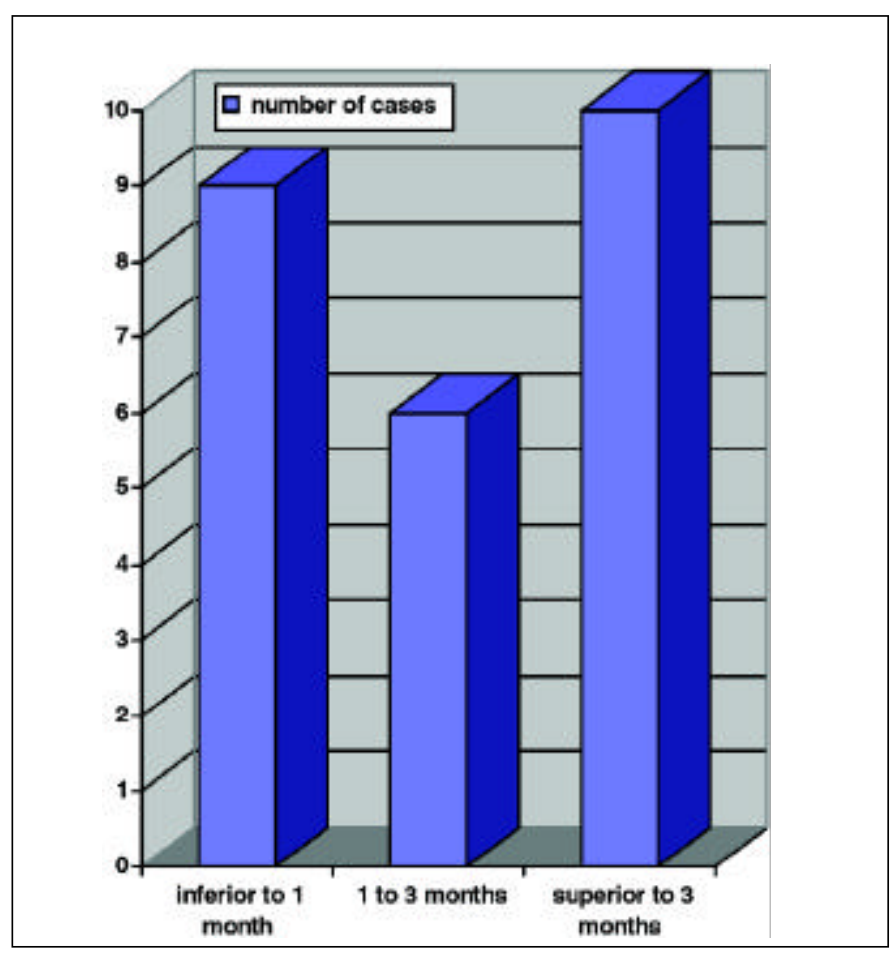

Graph 2 - Time in months of existing retinal detachment before surgery according to information obtained from 25 patients

\section{REFERENCES}

1. Welch RB. A survey of retinal detachment surgeons on the use of cryotherapy or diathermy. Am J Ophthalmol 1970;69:749-54.

2. Bonnet M, Mories O. Etude pilote de la photocoagulation trans-sclérale des déchirures rétiniennes avec le laser à diode. $\mathrm{J}$ Fr Ophthalmol 1994;17:739-45.

3. Campochiaro PA, Kaden IH, Vidauri-Leal J, Glaser BM. Cryotherapy enhances intravitreal dispersion of viable retinal pigment epithelial cells. Arch Ophthalmol 1985;103:434-6.

4. Haller JA, Blair N, De Juan JR E, De Bustros S, Goldberg MF, Muldoon T, Packo K, Resnick K, Rosen R, Shapiro M, Smiddy W, Walsh J. Transscleral diode laser retinopexy in retinal detachment surgery: results of a multicenter trial. Retina 1998;18:399-404.

5. Haller JA, Lim JI, Goldberg MF. Pilot trial of transscleral diode laser retinopexy in retinal detachment surgery. Arch Ophthalmol 1993;111:952-6.

6. Machemer R, Aaberg TM, Freeman HM, Irvine AR, Lean JS, Michels RG. An updated classification of retinal detachment with proliferative vitreoretinopathy. Am J Ophthalmol 1991;112:159-65.

7. Marmor MF. Mechanisms of normal retinal adhesion. In: Ryan SJ. Retina. St. Louis: Mosby; 1994. p.1931-53.

8. Farah ME, Motta MMS. Comparação entre diatermia e crioterapia em esclera delaminada na cirurgia de descolamento de retina. Arq Bras Oftalmol 1981;44:212-3.

9. Lincoff H, McLean JM, Nano H. Cryosurgical treatment of retinal detachment. Trans Am Acad Ophthalmol Otol 1964;68:412-32.

10. Glaser BM, Vidaurri-Leal J, Michels RG, Campochiaro PA. Cryotherapy during surgery for giant retinal tears and intravitreal dispersion of viable retinal pigment epithelial cells. Ophthalmology 1993;100:466-70.

11. Gonçalves JCM. Laser de diodo. Arq Bras Oftalmol 1996;59:103-4,

12. Nanda SK, Han DP. Experimental transconjunctival diode laser retinal photocoagulation through silicone scleral exoplants. Arch Ophthalmol 1995; 113:926-31.

13. Arrindell EL, Wu JC, Wolf MD, Nanda S, Han DP, Wong EC, Abrams GW, Mieler WF, Hyde JS. High-resolution magnetic resonance imaging evaluation of blood-retinal barrier integrity following transscleral diode laser treatment. Arch Ophthalmol 1995;113:96-102.

14. Häring G, Wiechens B. Long-term results after scleral buckling surgery in uncomplicated juvenile retinal detachment without proliferative vitreoretinopathy. Retina 1998;18:501-5. 